\title{
ANALISIS USAHA AYAM KAMPUNG SUPER DENGAN PEMBERIAN EKSTRAK KUNYIT DAN MENGKUDU
}

\author{
Analyzing Business of the Kampung Super Chicken by Turmeric Extract \\ and Morinda in Feed
}

\author{
Mufidah Muis $^{1}$ dan Besse Kurniyati Warisman ${ }^{2}$ \\ ${ }^{1}$ Jurusan Pertanian, Politeknik Pembangunan Pertanian Gowa \\ ${ }^{2}$ Program Studi Penyuluhan Peternakan \& Kesejahteraan Hewan, Politeknik Pembangunan Pertanian Gowa \\ e-mail: mufidahmuis@gmail.com
}

Received: 24 Januari 2020; Accepted: 29 Februari; Published: 30 Juni 2020

\begin{abstract}
ABSTRAK
Kajian ini bertujuan untuk mengetahui pemahaman peternak tentang analisis usaha ternak ayam kampung super ditinjau dari aspek sosial dan aspek ekonomi. Jenis kajian yang dilaksanakan adalah Analisis Usaha Ternak Ayam Kampung Super ditinjau dari aspek sosial dan aspek ekonomi dari tingkat pendapatan dan juga untuk mengetahui apakah pemeliharaan ayam kampung super dapat memberikan keuntungan bagi masyarakat . Usaha ternak ayam kampung super dalam satu periode adalah layak untuk diusahakan karena nilai R/C Ratio $1.95>1$ berada pada perlakuan P3 berarti menguntungkan peternak dengan pengeluaran biaya sebesar Rp. 1000 , akan memperoleh keuntungan sebesar $\mathrm{Rp} \mathrm{1.950,} \mathrm{dan} \mathrm{B/C} \mathrm{ratio} \mathrm{usaha} \mathrm{ternak} \mathrm{ayam}$ kampung super adalah 2,61 terdapat pada perlakuan P3. nilai BEP per unit 15.60/kg, terdapat diperlakuan P3 dan BEP harga sebesar Rp. 25.668/kg. Hasil evaluasi yang telah dilakukan diketahui bahwa responden setelah mengikuti penyuluhan, mereka memperoleh peningkatan pengetahuan $(42.8 \%)$ perubahan sikap $(44.6 \%)$ dalam usaha ternak ayam kampung super. Hasil evaluasi efektifitas $(68.38 \%)$ berada dalam kategori efektif.
\end{abstract}

Kata kunci: Analisis usaha, ayam kampung super, $\mathrm{R} / \mathrm{C}$ ratio, $\mathrm{B} / \mathrm{C}$ ratio dan $\mathrm{BEP}$

\section{ABSTRACT}

This study aims to determine the understanding of farmers about local chicken farm business analysis in terms of social and economic aspects. The type of study carried out is the Kampung Super Chicken Business Analysis in terms of social and economic aspects of the level of income and also to find out whether the maintenance of super native chicken can benefit the community. The super chicken farm business in one period is feasible because the value of $R / C$ Ratio 1.95> 1 is in the treatment of P3 means that it benefits the farmer with an expenditure of $R p .1000$, will get a profit of $R p 1.950$, and the $B / C$ ratio of super native chicken farming is 2.61 in the P3 treatment. BEP value per unit of $15.60 / \mathrm{kg}$, there is a $P 3$ and BEP price of $R p .25 .668 / \mathrm{kg}$. The results of the evaluation that have been carried out are known that the respondents after attending counseling, they gained increased knowledge (42.8\%) changes in attitude (44.6\%) in the business of super native chicken. The effectiveness evaluation results (68.38\%) are in the effective category.

Keywords: Business analysis, superior organic chicken, $R / C$ ratio, $B / C$ ratio and $B E P$

\section{PENDAHULUAN}

Peningkatan perekonomian di Indonesia sebagian besar dipengaruhi oleh pertumbuhan di sektor industri dan sektor pertanian. Sektor industri dan sektor pertanian saling berkaitan

Diterbitkan Oleh,

Unit Penelitian dan Pengabdian Masyarakat, Politeknik Pembangunan Pertanian Gowa

http://ejournal.polbangtan-gowa.ac.id sebab bahan baku dalam proses industri didapatkan dari sektor pertanian, oleh sebab itu sektor pertanian memiliki peranan penting dalam perekonomian di Indonesia. Sektor pertanian identik dengan sistem agribisnis dengan berbagai 
subsektornya yakni tanaman pangan dan hortikultura, perkebunan, kehutanan dan peternakan.

Ayam kampung super adalah salah satu jenis ayam lokal yang banyak dibudidayakan di wilayah Indonesia. Ayam kampung super termasuk dalam golongan ayam lokal, yang merupakan persilangan antara ayam lokal jantan dengan ayam ras betina (Iskandar, 2009). Jenis ayam inni banyak ditemukan diberbagai wilayah baik wilayah pedesaan maupun wilayah perkotaan (Wiranata et al., 2013). Penyebaran ketersediaan ayam kampung super yang cukup luas ini menjadikan ayam kampung super menjadi sumber yang potensial untuk memenuhi kebutuhan protein hewani masyarakat Indonesia.

Kesadaran masyarakat dan banyak permintaan konsumen untuk kebutuhan daging ayam kampung meningkat dan banyak dikembangkan sebagai usaha peternakan ayam kampung super. Ayam kampung super merupakan hasil persilangan antara ayam kampung pejantan yang berpostur tubuh besar (ayam bangkok) dengan ayam betina ras petelur, sehingga didapatkan ayam jenis unggul dengan pertumbuhan yang lebih cepat dibandingkan ayam lokal (buras). Ayam Kampung Super memiliki pertumbuhan yang cukup cepat dibandingkan dengan ayam kampung biasa meski lebih lama jika dibandingkan ayam broiler. Dalam masa pemeliharaan 45 sampai 60 hari ayam kampung super sudah bisa dipanen.

\section{BAHAN DAN METODE}

\section{Alat dan Bahan}

Tugas Akhir (TA) dilaksanakan di Politeknik Pembangunan Pertanian (Polbangtan) Gowa dan penyuluhan diadakan di kelompok tani peternak Di Kelurahan Bontoa, Kecamatan Mandai, Kabupaten Maros, Provinsi Sulawesi Selatan. Pada bulan Maret sampai bulan Mei 2019.

\section{Metode pelaksanaan}

Populasi peternak yang mempunyai usaha ternak ayam kampung super yang bertempat tinggal di Kelurahan Bontoa, Kecamatan Mandai, Kabupaten Maros. Pengambilan sampel dilakukan secara sengaja (purposive sampling).

\section{Teknik pengumpulan}

Teknik pengumpulan data yang digunakan untuk mendapatkan data primer dan data sekunder dalam penelitian ini yaitu :

1. Observasi, yaitu pengumpulan data melalui pengamatan langsung terhadap objek penelitian.

2. Wawancara langsung, untuk mengumpulkan data perorangan dari responden dengan mengajukan pertanyaanpertanyaan untuk memperoleh informasiinformasi yang dibutuhkan, serta memberikan kuisioner pada peternak.

3. Melakukan dokumentasi pengumpulan data yang relevan dengan penelitian yaitu data yang tersedia pada instansi atau lembaga terkait berupa laporan-laporan dan berbagai kepustakaan.

\section{Analisis data}

Analisis kelayakan usaha atau disebut juga feasibility study adalah kegiatan untuk menilai sejauh mana manfaat yang dapat diperoleh dalam melaksanakan suatu kegiatan usaha. Hasil analisis ini digunakan sebagai bahan pertimbangan dalam mengambil keputusan, apakah menerima atau menolak dari suatu gagasan usaha. Pengertian layak dalam penelitan ini adalah kemungkinan dari gagasan suatu usaha yang akan dilaksanakan dapat memberikan manfaat dalam arti finansial maupun sosial benefit. Dengan adanya analisis kelayakan ini diharapkan risiko kegagalan dalam memasarkan produk dapat dihindari (Resya, 2011).

\section{Parameter}

1. Analisis penerimaan dan pendapatan

Pendapatan $=$ Total penerimaan - total biaya $P D=T P-T B$

\section{Keterangan: PD: Pendapatan \\ TP: Total Penerimaan \\ TB: Total biaya}

\section{2. $R / C$ ratio}

Revenue/cost ratio adalah merupakan perbandingan antara total penerimaan dengan total biaya dengan rumusan sebagai berikut:

$$
\text { Revenue Cost Ratio }(\mathrm{R} / \mathrm{C})=\frac{T R(\text { Total penerimaan })}{T C(\text { Total pengeluaran })}
$$


Jika $\mathrm{R} / \mathrm{C}$ ratio $>1$, maka usaha yang dijalankan mengalami keuntungan atau layak untuk dikembangkan. Jika R/C ratio < 1, maka usaha tersebut mengalami kerugian atau tidak layak untuk dikembangkan. Selanjutnya jika R/C ratio $=1$, maka usaha berada pada titik impas (break event point) (Soekartawi, 2006).

\section{Break Event Point (BEP)}

Analisis break event point (titik impas) suatu metode analisis yang digunakan untuk mengetahui hubungan antara beberapa variabel dalam suatu usaha yang menggambarkan posisi biaya total sama dengan pendapatan total, yang biasa disebut titik impas. Break even point ini digunakan untuk menganalisis produksi berapa banyak jumlah telur yang diproduksi atau berapa banyak uang yang dikeluarkan. Titik Impas (BEP produksi ) usaha ternak itik dapat dicapai dengan perhitungan sebagai berikut:

$$
B E P \text { produksi }(\mathrm{kg})=\frac{\text { Total biaya }}{\text { Harga penjualan }}
$$

Titik impas (BEP harga) usaha ternak itik dapat dicapai dengan perhitungan sebagai berikut :

$$
B E P \text { harga }(R p)=\frac{\text { Total biaya }}{\text { Total produksi }}
$$

BEP produksi daging diketahui dengan membagi total biaya dengan harga penjualan daging ayam kampung super.

Metode yang digunakan untuk mengetahui tingkat pengetahuan, sikap adalah dengan menggunakan rating scale atau skala nilai, kemudian ditabulasi dan diolah dengan menggunakan garis continum (Padmowiharjo, 2002).

Rumus yang digunakan adalah:

Tabel 1. Analisis usaha ternak ayam kampung super
Tingkat $P S=\frac{\text { Jumlah jawaban yang diperoleh }}{\text { Nilai tertinggi yang diperoleh }} \times 100 \%$

Selanjutnya hasil dari post test dan pre test ditabulasi untuk mengetahui tingkat efektifitas penyuluhan berdasarkan kategori nilai yang didapatkan. Sedangkan untuk mengetahui peningkatan efektifitas penyuluhan menggunakan rumus (ginting, 1991) yaitu:

$$
E P=\frac{\mathrm{PS}-\mathrm{PR}}{(\mathrm{N} .4 \mathrm{Q})-\mathrm{PR}} \times 100 \%
$$

Keterangan:

$\begin{array}{ll}\text { EP } & \text { : Efektivitas penyuluhan } \\ \mathrm{Ps} & \text { : Tes akhir (post test) } \\ \mathrm{Pr} & \text { : Test awal (pre test) } \\ \mathrm{N} & \text { : Jumlah responden } \\ 4 & \text { : Nilai tertinggi } \\ \mathrm{Q} & \text { : Jumlah pertanyaan } \\ 100 \% & \text { : Pengetahuan yang ingin dicapai } \\ \mathrm{Ps}-\mathrm{Pr} & \text { : Peningkatan pengetahuan } \\ \mathrm{N} .4 . \mathrm{Q}-\mathrm{Pr} & \text { : Nilai kesenjangan } \\ \text { Maka kriteria presentase efektivitas penyuluhan: } \\ \leq 32 \quad \text { : Kurang efektif } \\ 32-64 \quad \text { : Cukup efektif } \\ \geq 64 \quad \text { : Efektif }\end{array}$

\section{HASIL DAN PEMBAHASAN}

Biaya produksi adalah total biaya yang dikeluarkan selama satu periode produksi yang terdiri dari biaya tetap atau biaya yang tidak dipengaruhi oleh kapasitas produksi dan biaya variabel atau biaya yang berubah-ubah dan besarnya tergantung dari besar kecilnya kapasitas produksi. Pada Tabel 1 total biaya Pengeluaran selama satu periode Analisis usaha ayam kampung super rata-rata Rp. 700.000,- yang terdiri dari biaya tetap sebesar Rp 198.000,- dan biaya variabel rata-rata $\mathrm{Rp} 500.000$,- di dukung oleh (Putong, 2002).

\begin{tabular}{cccc}
\hline Uraian & Biaya Variabel & Biaya Tetap & Jumlah \\
\hline P0 & Rp. 578.380,- & Rp. 198.000,- & Rp. 776.380,- \\
P1 & Rp. 582.536,- & Rp. 198.000,- & Rp. 780.536,- \\
P2 & Rp. 583.136,- & Rp. 198.000,- & Rp. 781.136,- \\
P3 & Rp. 582.310,- & Rp. 198.000,- & Rp. 780.310,- \\
\hline
\end{tabular}

Diterbitkan Oleh, 
Tabel 2. Analisis usaha ternak ayam kampung super

\begin{tabular}{|c|c|c|c|c|c|}
\hline \multirow{2}{*}{ No } & \multirow{2}{*}{ Uraian } & \multicolumn{4}{|c|}{ Perlakuan } \\
\hline & & $\mathrm{P} 0$ & P1 & $\mathrm{P} 2$ & P3 \\
\hline 1. & Berat awal ayam & $1.06 \mathrm{Kg}$ & $1.06 \mathrm{Kg}$ & $1.11 \mathrm{Kg}$ & $1.05 \mathrm{Kg}$ \\
\hline 2. & Berat akhir ayam & $1.70 \mathrm{Kg}$ & $1.85 \mathrm{Kg}$ & $1.86 \mathrm{Kg}$ & $1.90 \mathrm{Kg}$ \\
\hline 3. & Harga pakan & Rp. 402.380,- & Rp. 403.806,- & Rp. 403.496 & Rp. 401.760,- \\
\hline 4. & Harga air minum & - & Rp. 2.730,- & Rp. 3.640,- & Rp. 4.550,- \\
\hline 5. & Sewa listrik & Rp. 12.500,- & Rp. 12.500,- & Rp. 12.500,- & Rp 12.500,- \\
\hline 6. & Sewa kandang & Rp. 83.250,- & Rp. 83.250,- & Rp. 83.250,- & Rp. 83.250,- \\
\hline 7. & Modal usaha & Rp.867.130,- & Rp. 871.286,- & Rp. 871.286,- & Rp. 871.060,- \\
\hline 8. & Gaji pekerja & Rp. 125.000,- & Rp. 125.000,- & Rp. 125.000,- & Rp. 125.000,- \\
\hline 9. & $\begin{array}{l}\text { Harga jual ayam } \\
(\mathrm{kg})\end{array}$ & Rp. 50.000,- & Rp. 50.000,- & Rp. 50.000,- & Rp. 50.000,- \\
\hline 10. & $\mathrm{R} / \mathrm{C}$ ratio & 1.75 & 1.89 & 1.90 & 1.95 \\
\hline & $\mathrm{B} / \mathrm{C}$ ratio & 2.35 & 2.54 & 2.55 & 2.61 \\
\hline 13. & BEP harga & Rp. 28.543,- & Rp. 26.369,- & Rp. 26.247,- & Rp. $25.668,-$ \\
\hline
\end{tabular}

Pendapatan yang didapatakan selama penelitian di atas meningkat dari perlakuan P0P3. Hal ini di karenakan berat badan yang bertambah setiap perlakuan.

Berdasarkan Tabel 2 di atas menunjukkan bahwa analisis usaha $\mathrm{R} / \mathrm{C}$ ratio, $\mathrm{B} / \mathrm{C}$ ratio, dan $\mathrm{BEP}$ adalah besaran nilai yang menunjukan perbandingan antara penerimaan usaha (Revenue $=\mathrm{R})$ dengan total biaya (Cost $=$ C). Mulyadi (1997), ada 3 (tiga) kemungkinan yang diperoleh dari perbandingan antara penerimaan $(\mathrm{R})$ dengan biaya $(\mathrm{C})$, yaitu $: \mathrm{R} / \mathrm{C}=$ $1 ; \mathrm{R} / \mathrm{C}>1$ dan $\mathrm{R} / \mathrm{C}<1$. Berdasarkan $\mathrm{R} / \mathrm{C}$ ratio yang diamati menunjukkan bahwa nilai $\mathrm{R} / \mathrm{C}$ ratio tertinggi berada pada perlakuan $\mathrm{P} 3$ dengan nilai 1.95 dan nilai $\mathrm{R} / \mathrm{C}$ ratio terkecil berada pada perlakuan P0 (1.75), artinya setiap pengeluaran 1 rupiah biaya yang akan dihasilkan sebesar sebesar 1.95 rupiah.

$\mathrm{R} / \mathrm{C}$ ratio usaha ayam kampung super sebesar $1.95>1$. Hal ini menunjukkan hasil yang menguntungkan yang berarti setiap mengeluarkan rupiah akan menghasilkan 1.950 rupiah. Usaha ayam kampung kampung super akan dikatakan efisien apabila usaha ternak telah mampu menggunakan sumber dana yang dimiliki sebaik mungkin untuk melengkapi kebutuhan usahanya (Hartono et al., 2013).
$\mathrm{B} / \mathrm{C}$ ratio adalah besaran nilai yang menunjukan perbandingan antara laba bersih (benefit $=\mathrm{B}$ ) dengan total biaya $(\operatorname{cost}=\mathrm{C})$. Dalam batasan besaran nilai $\mathrm{B} / \mathrm{C}$ dapat diketahui apakah suatu usaha menguntungkan atau tidak menguntungkan. Jika $\mathrm{B} / \mathrm{C}$ ratio $>0$, maka usaha yang dijalankan mengalami keuntungan atau prospek untuk dikembangkan. Jika B/C ratio $<0$, maka usaha tersebut mengalami kerugian atau tidak layak untuk dikembangkan. Selanjutnya jika $\mathrm{B} / \mathrm{C}$ ratio $=0$. Berdasarkan $\mathrm{B} / \mathrm{C}$ ratio diatas sangat layak dijadikan usaha karena $\mathrm{B} / \mathrm{C}$ ratio $>$ 1. Untuk lebih jelasnya dapat dilihat pada perlakuan $\mathrm{P} 3$ dengan nilai $\mathrm{B} / \mathrm{C}$ ratio 2.61 .

BEP memiliki dua pendekatan penetapan yaitu BEP harga dan BEP unit. BEP harga untuk ayam kampung super dapat diketahui dengan cara menghitung total pengeluaran dibagi dengan volume produksi yang dapat

BEP harga menjelaskan besarnya harga minimal perunit barang yang ditetapkan produsen (Mulyadi, 1997). Penjualan ayam kampung super akan berada diposisi BEP atau kembali modal jika harga jualnya hanya Rp. 28.543,- untuk P0, Rp. 26.369,- untuk P1, Rp. 26.247,- untuk P2, dan Rp. 25.668,- untuk P3, Jadi nilai BEP harga terndah berada pada perlakuan P3. Namun jika ingin untung maka harga penjualan harus diatas

Diterbitkan Oleh, 
BEP harga. Jika dibawah BEP harga maka usaha akan rugi atau tidak kembali modal. BEP satuan menjelaskan jumlah produksi minimal yang harus dihasilkan oleh produsen (Mulyadi, 1997). Nilai BEP unit sebesar 15.53 untuk P0, 15.61 untuk P1, 15.62 untuk P2, dan 15.60 untuk P3 akan kembali modal jika ternak ayam kampung super yang terjual setiap perlakuan sebanyak \pm 15 $\mathrm{kg}$.

\section{Penyuluhan}

Efektivitas penyelenggaraan penyuluhan di Kelurahan Bontoa mendapatkan nilai $68.38 \%$ dan berada dalam kategori efektif (Ginting, 1991). Hal ini menunjukan bahwa kegiatan penyelenggaraan penyuluhan analisis usaha ternak ayam kampung super efektif dimana kriteria berada pada $>64 \%$

Tabel 3. Hasil rekapitulasi tingkat perubahan dan peningkatan pengetahuan dan sikap di Kelurahan Bontoa, Kecamatan Mandai, Kabupaten Maros.

\begin{tabular}{lcccrcccc}
\hline & \multicolumn{3}{c}{ Nilai } & \multicolumn{3}{c}{ Perubahan } \\
\cline { 2 - 8 } Deskripsi & Nilai max & $\begin{array}{c}\text { Tes } \\
\text { awal }\end{array}$ & $(\%)$ & $\begin{array}{c}\text { Tes } \\
\text { Akhir }\end{array}$ & $(\%)$ & Nilai & $(\%)$ \\
\hline Pengetahuan & 500 & 185 & 37,0 & 399 & 79,8 & 214 & 42,8 \\
Sikap & 500 & 176 & 35,2 & 399 & 79,8 & 223 & 44,6 \\
\hline
\end{tabular}

\section{KESIMPULAN}

Berdasarkan hasil pembahasan kajian, dapat disimpulkan sebagai berikut.

1. Usaha peternakan ayam kampung super sudah layak dijadikan sebagai usaha dan menguntungkan karena memiliki nilai $\mathrm{R} / \mathrm{C}$ ratio $1.95>1$, dengan nilai BEP Harga yang didapatkan 25.668 dan BEP per unit 15.60 Dan $\mathrm{B} / \mathrm{C}$ ratio dalam usaha ayam kampung super yaitu 2.35 sampai 2.61 maka sangat layak untuk dikembangkan $\mathrm{B} / \mathrm{C}>0$.

2. Berdasarkan hasil evaluasi yang telah dilakukan, diketahui bahwa responden setelah mengikuti penyuluhan, mereka memperoleh peningkatan pengetahuan (79.8\%) perubahan sikap (79.8\%) dalam usaha ternak ayam kampung super. Hasil evaluasi efektivitas $(68.38 \%)$ berada dalam kategori efektif.

\section{SARAN}

1. Diharapkan petani atau peternak mengerti, memahami dan dapat menganalisis yang benar sehingga diperoleh hasil yang akurat dalam usaha ternak ayam kampung super.

2. Perlu adanya sosialisasi lebih lanjut mengenai analisis usaha ternak ayam kampung super agar dapat bermanfaat bagi petenak dan keluarganya.

\section{DAFTAR PUSTAKA}

Ginting,E.1991.Metode Kuliah Kerja Lapangan . Universitas Brawijaya, Malang.

Hartono, E.F., N.N. Hidayat, dan Roesdiyanto. 2013. Kinerja ekonomi usaha ayam sentul di Kabupaten Ciamis. Jurnal Ilmiah Peternakan. 1(3):865-873

Padmowihardjo, S, 2002. Evaluasi Penyuluhan Pertanian. Materi pokok LUHT 4430/2 SKS/ 1- 6 Universitas Terbuka. Jakarta

Putong, I., 2002. Ekonomi Mikro dan Makro. Ghalia Indonesia. Jakarta Resya,Olivia. 2011. Analisis Kelayakan Usaha http://oliviaresya.blogspot.com/2011/04/ .html.(on line). Diakses Tanggal 19 Juli 2019 pada Pukul 20.40. WIB 